\title{
DISCURSOS SOBRE GÊNERO NA PUBLICIDADE PÓS-MASSIVA: UM ESTUDO DO VIDEOCASE "BADASS" À LUZ DA SEMIÓTICA SINCRÉTICA DISCOURSE ABOUT GENDER IN POST-MASSIVE ADVERTISING: A STUDY OF THE "BADASS” VIDEOCHASE THROUGH SYNCRETIC SEMIOTICS
}

\author{
Emerson Campos GONÇALVES \\ Universidade Federal do Espírito Santo (UFEs) \\ emer.cg@gmail.com \\ Robson LOUREIRO \\ Universidade Federal do Espírito Santo (Ufes) \\ robson.loureiro@ufes.br
}

\begin{abstract}
Resumo. Na última década, o mundo experimentou a consolidação de um novo modelo comunicacional, marcado pelo estabelecimento de um momento que teóricos como Pierre Lévy e André Lemos (2010) têm convencionado chamar de era pós-massiva. A principal característica desse período é a liberação da palavra para os indivíduos, que deixam de ser meros receptores da informação e passam a produzir e interagir de forma mais franca com o conteúdo. Nesse contexto, tornou-se inevitável o choque entre as temáticas conservadoras impostas pelos mass media - tradicional fonte de formação da opinião pública - e as progressistas, presentes sobretudo em pautas consideradas de minoria, como a dos movimentos Feminista e LGBT. Destarte, esta pesquisa aproveita o polêmico videocase "Badass", produzido pela Agência Fischer, para observar à luz da semiótica sincrética como as intenções dos enunciadores - explicitadas pelas avaliações dos diferentes planos de conteúdo e expressão sobrepostos - entram em colapso com as expectativas dos enunciatários. Assim, busca contribuir para o avanço dos debates sobre os processos não-formais de educação na Web 2.0 à luz da semiótica sincrética.
\end{abstract}

Palavras-chave: publicidade - semiótica sincrética - era pós-massiva - gênero

\begin{abstract}
In the last decade, the world has experienced the consolidation of a new communication model, marked by the establishment of a moment in which theorists like Pierre Lévy and André Lemos (2010) have agreed to denominate the post-massive era. The main characteristic of this period is the liberation of the word to individuals, who cease to be mere information receptors and begin to produce and interact more freely with the content. In this context, the clash between the conservative themes imposed by the mass media - traditional source of public opinion's formation - and the progressives, who are mainly present in minority movements such as the Feminist and LGBT groups is inevitable. Thus, this research takes advantage of the videocase "Badass", a controversial video produced by the advertising agency Fischer, to observe, through syncretic semiotics, how the intentions of the enunciators - made explicit by the evaluation of different plans of content and expression that overlap - collapse with the expectations of the enunciates. Thus, this work seeks to contribute to the advance of debates about non-formal processes of education in Web 2.0 under the light of syncretic semiotics.
\end{abstract}

Keywords: advertising - syncretic semiotics - post-massive era - gender

\section{Introdução}

Na última década, parte significativa do globo experimentou a consolidação de um novo jogo comunicacional, desenvolvido em uma rede de mensagens tão complexa como possível (PRIMO, 2003), capaz de colocar em xeque modelos que imperaram durante mais de um século enquanto prática estabelecida dos mass media (meios de comunicação de massa). Trata-se do advento das redes sociais online, fenômeno 
emblemático de um período que teóricos como Pierre Lévy e André Lemos (2010) têm convencionado chamar de era pós-massiva ou Web 2.0 ${ }^{1}$. Esses novos tempos (ou nova era) são marcados pelo rompimento do tradicional fluxo verticalizado da comunicação (um para todos), condicionando o nascimento de uma troca de mensagens mais horizontalizada e distribuída em rede (todos para todos), notoriamente marcada pela liberação da palavra para os indivíduos. Esses, antes considerados meros receptores (enunciatários), agora passam a exercer, também, o papel de emissores e coautores de conteúdo, metamorfoseando-se em interagentes ${ }^{2}$.

Entre outras quebras de paradigma, tal mudança provoca o rompimento da ditadura da informação imposta, até então, pelos gatekeepers ${ }^{3}$ dos grandes grupos de comunicação e agências de publicidade, que figuravam como os únicos responsáveis por selecionar e dar crivo sobre quais debates eram de interesse público ou não. Nesse sentido, mais do que uma "novidade" com poder de exterminar as estruturas de informação existentes na sociedade, a era pós-massiva pode representar uma chance única de repensá-las em sua concepção mais purista no que diz respeito aos processos de formação dos indivíduos, através dos meios de comunicação de massa. Isso porque no contra fluxo do que se poderia esperar - o processo educativo fomentado pelos mass media, se não sempre, em grande parte de sua história secular caminhou em direção aos anseios e interesses econômicos dos grupos detentores dos meios de comunicação (e do poder da palavra) e seus principais financiadores, funcionando como Aparelhos Ideológicos do Estado responsáveis por alienar os indivíduos (ALTHUSSER, 1985) e manter o status dominante daqueles que detêm o poder, perdendo sua potência educadora libertária.

Para entender o referido "poder libertador", que aqui se atribui ao exercício ideal da Comunicação Social (o mesmo que foi perdido ou nunca vingou na era massiva), retomemos Paulo Freire. Embora não tenha se dedicado a debater, de maneira mais exaustiva (e consequentemente aprofundada), o papel dos mass media na formação dos

\footnotetext{
${ }^{1}$ Trocadilho com o tipo de notação em informática que indica a versão de um software, o termo Web 2.0 designa a segunda geração de serviços online e se caracteriza por potencializar as formas de publicação, além de ampliar os espaços para a interação entre os participantes do processo comunicativo na rede (PRIMO, 2007).

${ }^{2}$ Alex Primo (2003) propõe o termo interagente para substituir a comum definição de usuário (ou receptor) que é dada aos consumidores da informação na Web 2.0. Para ele, é inadequado tratar esse público como quem apenas 'usa' determinado conteúdo, uma vez que a era pós-massiva permite a interação e produção.

${ }^{3} \mathrm{Na}$ teoria do gatekeeper, o processo de produção da informação é concebido como uma série de escolhas onde o fluxo de notícias/informações tem que passar por diversos gates (portões) controlados pelos redatores e jornalistas.
} 
indivíduos, Freire jamais se furtou ao assunto, dando ênfase para as semelhanças entre os papéis da escola e da imprensa, em vários trechos de suas obras (MEDITSCH e FARACO, 2003). Em uma das abordagens sobre o tema que ficaram mais notórias, presente em Pedagogia do Oprimido, o educador critica os meios de comunicação de massa, por agirem como instituições antidialógicas e comprometidas com o depósito de conteúdos em indivíduos-objetos, sem a criticidade necessária para a libertação dos sujeitos da opressão e a consequente transformação de mundo (FREIRE, 1978). É a partir dessa crítica de Freire, que encontramos a essência que - em uma visão mais otimista - pode ser recuperada na era pós-massiva: a liberação do poder de fala para os indivíduos a partir da inteligência coletiva ${ }^{4}$.

Entre os sinais positivos para o estabelecimento concreto da supracitada inteligência coletiva, destaca-se o notório fortalecimento das culturas de nicho na internet, o que possibilitou que movimentos sociais tratados como minoria ganhassem voz, ampliando o espaço de participação e debate dos mesmos, na esfera pública. Entre esses, é possível destacar o protagonismo dos grupos que trazem como agenda a igualdade racial, como os movimentos Indígena, Negro e Quilombola, e de gênero, sobretudo os movimentos LGBT e Feminista. Para além da possibilidade de estabelecerem novos parâmetros - mais isonômicos -, no debate que fomenta a formação da opinião pública acerca dos assuntos de seu interesse, esses movimentos encontraram na Web 2.0 um espaço privilegiado para o choque com o discurso tradicional, confrontando diretamente diferentes pontos de reflexão sobre uma temática. É disso que este artigo trata nos tópicos que seguem: do choque entre a produção de significados sobre gênero, pretendida pelos tradicionais agentes dos mass media (aqui ilustrados pela agência de publicidade Fischer), com a produção esperada pelos interagentes na era pós-massiva (representados neste estudo pelos adeptos e simpatizantes das ações discursivas dos movimentos LGBT e Feminista). Para avaliar tal confronto discursivo, este estudo parte de uma discussão inicial sobre o papel da publicidade na educação, apresenta o corpus de pesquisa, perpassa o debate sobre a semiótica sincrética, como método de análise, e realiza um estudo de caso a partir das teorias visitadas.

\footnotetext{
${ }^{4}$ Lemos e Lévy definem a inteligência coletiva como o resultado de uma "transformação da esfera midiática pela liberação da palavra que se dá com o surgimento de funções comunicativas pós-massivas que permitem a qualquer pessoa, e não apenas empresas de comunicação, consumir, produzir e distribuir informação sob qualquer formato em tempo real e para qualquer lugar do mundo" (LEMOS; LÉVY, 2010 , p. 25).
} 


\section{Publicidade como agente de educação: debates sobre gênero}

É acertado e imperativo lembrar que, em sua essência, toda produção publicitária mira o convencimento ou a persuasão de um determinado público de enunciatários (CARRASCOZA, 1999), tomando tal tarefa como ponto de origem e fim desejados para os diferentes enunciados. Em outras palavras, para além dos importantes debates sobre consumo, segmentação e "propagabilidade", na era pós-massiva, pode-se afirmar que o principal objetivo da produção publicitária continua sendo a apropriação, como estratégia argumentativa, de um conjunto de verdades e sentidos postos que perpassam ou estão nas bases da opinião pública. Em outros termos, é notável que o estereótipo neste trabalho tomado como voz da opinião comum, da moral rasteira, a doxa - é estratégia recorrente às práticas publicitárias, como reforça a pesquisadora Maria Lúcia Vissotto Diniz:

Por representar um signo que restringe o sentido, o estereótipo é uma
estratégia discursiva do sujeito da enunciação que, na colocação em discurso,
garante a comunicação oral, escrita ou visual - e a significçãao pretendida -
na práxis enunciativa (interação enunciador-enunciatário) (DINIZ, 2006,
p.137).

À margem da utilização em larga escala e de sua pressuposta natureza rasteira/superficial, faz-se necessário afirmar que o estereótipo, ao estabelecer e confirmar um sentido pronto, acaba corroborando normas estabelecidas, ainda que essas representem discursos conservadores (por exemplo, aqueles machistas, como no caso estudado neste artigo, no tópico 4). Em outras palavras, pode-se dizer de forma inequívoca que, ainda que não seja esse seu objetivo primeiro, o discurso publicitário atua como agente educativo e formador da opinião pública para com as diversas imagens que são apresentadas por outros setores dos mass media e da sociedade, questionando ou reafirmando valores sociais hegemônicos.

No que diz respeito à sexualidade e às questões de gênero, é fundamental destacar que a história de representação da mulher e dos homossexuais pelos mass media se configura como uma história de produção de significados misóginos e homofóbicos (SOIETH, 2001; MENDEZ, 2007; CARVALHO, 2012). Tomando a publicidade, é notório que esta, ao reproduzir imagens socialmente estabelecidas (estereotipadas), contribuiu em larga escala para perpetuar e fixar significados que criminalizaram e referendaram uma "patologização" dos corpos da mulher e do homossexual. Com a era pós-massiva, porém, os enunciatários tomam para si o papel de 
interagentes, questionando os sentidos postos (conforme discutido na introdução deste trabalho).

\subsection{Objeto e a escolha do corpus de pesquisa}

Tomando como objeto a ser pesquisado o choque discursivo de valores sobre as questões de gênero na publicidade pós-massiva, esta pesquisa adota como corpus para análise o videocase "Badass", peça produzida para a divulgação de um shampoo homônimo, voltado para o público masculino, da linha OX Men (fabricado pelo Grupo J\&F). Editado pela Agência Fischer - em atividade no Brasil desde 1981 -, o videocase escolhido explicita o conceito que norteou os profissionais de criação no desenvolvimento do design da embalagem do produto, apresentada em formato similar ao de uma garrafa de cerveja, como mostra a Imagem 1.

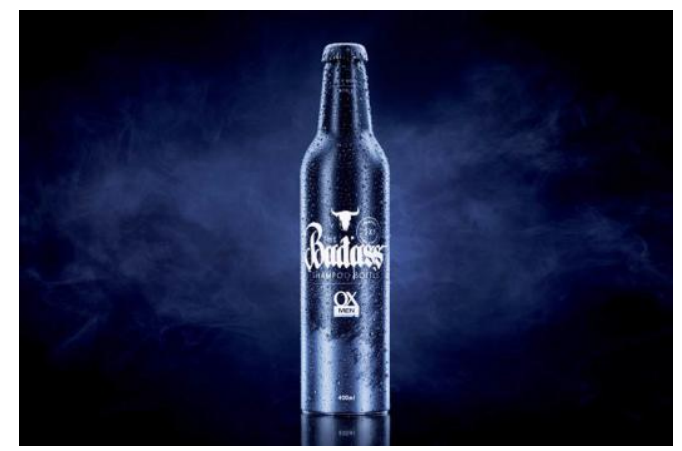

Com 94 segundos de duração, o vídeo editado para divulgar a elaboração da peça foi postado nos perfis oficiais da agência, no Youtube e no Facebook, em setembro de 2015 e republicado em abril de 2016, quando ganhou notoriedade depois da empresa conquistar o Bronze pela produção no Wave Festival - uma das principais premiações em Publicidade do país. Nessa segunda postagem, o material atingiu a marca de 695 mil visualizações e mais de 11 mil compartilhamentos.

A escolha do videocase "Badass" como corpus se justifica por se tratar de uma peça publicitária que reúne todas as características interessantes para debater o tema proposto nesta pesquisa, a saber: i) ser peça publicitária, presente no ambiente da Web 2.0, estando acessível aos interagentes (enunciatários) e, portanto, passível de sofrer intervenção e influência desses; ii) trazer como temática principal a discussão sobre gênero e sexualidade; iii) apresentar uma linguagem sincrética, característica dos mass media e, também, da era pós-massiva, permitindo a análise semiótica pretendida

\footnotetext{
${ }^{5}$ Disponível em https://www.youtube.com/watch?v=AjgBfQPTwVw Acesso em 05 de maio de 2016.
} 
(descrita no tópico 2); e iv) ser um case que suscitou grande debate e repercussão, de modo que, sabendo da impossibilidade de generalizar os resultados e dos limites da pesquisa proposta, garanta a investigação de um produto que teve grande impacto social e que possa fomentar novos estudos.

\section{Semiótica sincrética e modelo de análise}

Pode-se dizer que, ao longo da história secular dos mass media, a narrativa publicitária se caracterizou como aquela que, de maneira mais perceptível, busca experimentar e utilizar a seu favor a união de diferentes linguagens, verbais e nãoverbais, em um mesmo produto textual. Das clássicas criações impressas (ou offline), como panfletos e outdoors, às produções mais incrementadas para a televisão ou para as plataformas digitais, a multiplicação das linguagens utilizadas para compor um único texto tem sido uma estratégia eficaz ao criar um sentido de unidade mais potente, responsável por sensibilizar possíveis consumidores da ideia ou produto anunciados. Nesse sentido, tomar a possibilidade de um estudo de qualquer enunciado publicitário, sem considerar os diferentes elementos (verbais e não-verbais) que constituem esse texto de natureza sincrética e, ainda assim, objetivar uma avaliação de todas as produções de sentido disponíveis, parece um equívoco grave para qualquer pesquisador.

Ao buscar uma definição de textos sincréticos para seu trabalho com reportagens online, a pesquisadora Luciana Maria Crestani (2014) lembra que a teoria semiótica de Aldirdas Julien Greimas trabalha com dois tipos de sincretismo, sendo o primeiro tipo oriundo dos estudos de Hjelmslev sobre fonologia. A este trabalho, porém, interessa mais o segundo conceito de sincretismo estabelecido por Greimas que é a das chamadas semióticas sincréticas, definidas como "aquelas que se valem de várias linguagens de manifestação" (FIORIN, 2009, p.33). José Luiz Fiorin (2009) pondera que, embora a imprecisão da definição greimasiana tenha levado vários semioticistas a dizerem que sua problematização se afasta do sincretismo discutido por Hejelmslev, é equivocado ignorar o direcionamento teórico dado por Algirdas Julien Greimas. Nesse sentido, ele retoma os estudos empreendidos sobre tal definição por Jean-Marie Floch (1986).

Ao examinar o trabalho de Floch, Fiorin (2009) rebate algumas discussões trazidas pelo semioticista francês - como, por exemplo, de que o plano de expressão da semiótica sincrética caracteriza-se por uma pluralidade de substâncias para uma forma única -, mas, de modo mais amplo, debate e apresenta um conjunto de definições

presentes na obra de Jean-Marie Floch que contribui de forma decisiva, para 
estabelecermos um conceito de semiótica sincrética. Destaca-se o seguinte excerto, fundamental para a compreensão do conceito de semiótica sincrética, tão caro a esta pesquisa:

\begin{abstract}
Nas semióticas sincréticas, o sincretismo não é somente de conteúdo, mas também da forma de expressão [...]. O sincretismo da forma de expressão é, assim, o estabelecimento de uma forma de expressão distinta da forma de expressão de cada uma das semióticas que entram em sincretismo, pois os traços particulares de cada uma delas deixam de ser levados em conta [...]. Se houvesse uma enunciação para cada linguagem, o resultado seria colocar uma linguagem ao lado da outra, sem que houvesse uma superposição da forma de expressão e, por conseguinte, sem que dela resultasse um sincretismo. Ao contrário, temos uma única enunciação sincrética, realizada por um mesmo enunciador, que recorre a uma pluralidade de linguagens (FIORIN, 2009, p.37-38).
\end{abstract}

Aceitando o conceito de semiótica sincrética apresentado por José Luiz Fiorin (2009), faz-se necessário destacar as contribuições de Lúcia Teixeira (2009) e Ana Cláudia Oliveira (2009) com duas importantes - e distintas, em determinadas categorizações - avaliações metodológicas sobre a pesquisa dos enunciados sincréticos. Aqui tomaremos como base as postulações de Oliveira (2009), que sugere que um possível equívoco nas avaliações de objetos sincréticos está no fato de nossa própria percepção permanecer centrada no plano de conteúdo, ignorando que enunciados como o anúncio publicitário são formados por mais de um sistema.

Uma das razões desse procedimento metodológico deve-se à ênfase das
análises centradas no plano de conteúdo, mesmo aquelas que enfocam o
discurso. Essas deixam de considerar que todo o conteúdo só é manifesto por
uma expressão e que o ir e vir entre expressão e conteúdo aumenta a
compreensão dos efeitos de sentido produzidos (OLIVEIRA, 2009, p.80).

Ao destacar a importância de uma metodologia que abarque todos os sistemas presentes em um texto sincrético, capaz de considerar suas particularidades e diferenças, Oliveira propõe quatro tipos de sincretismo que convocam nossos sentidos a trabalhar de formas distintas: i) sincretismo por união de traços intersistêmicos, onde estes operam por reciprocidade; ii) sincretismo por separação dos traços intersistêmicos, com ocorrência em paralelismo, justaposições; iii) sincretismo por contração, onde a atuação de uma ordem sobrepõe a outra; e iv) sincretismo por difusão, onde ocorre uma múltipla convocação das ordens sensoriais.

Tomando as categorias de sincretismo propostas por Oliveira (2009), optou-se por adotar as importantes contribuições da pesquisa de Ana Silva Médola (2009) que, partindo da mesma base teórica, traz um refinamento metodológico fundamental para a análise de textos sincréticos no audiovisual, em seu artigo Lógicas de articulação de linguagens no audiovisual. É Médola (2009) quem propõe que uma primeira 
possibilidade de articulação sincrética está na lógica das relações de dependência entre as diferentes semióticas presentes no audiovisual. Destarte, citando Greimas, a autora propõe uma análise que comece no plano de conteúdo, de modo que seja possível depreender os contrastes passíveis de revelar relações de dependência, primeiro nas manifestações de oposições de base no nível profundo e, depois, nas dimensões temáticas e figurativas no nível superficial. "Partindo da segmentação desse todo de significação é que se voltará ao plano de expressão para a apreensão dos elementos visuais e sonoros" (MÉDOLA, 2009, p.411-412).

Desse modo, a pesquisadora estabelece a seguinte sequência, para o procedimento de investigação (adotada nesta pesquisa): i) análise do plano de conteúdo, com exemplificação das relações de dependência entre grandezas semióticas e o estabelecimento de categorias; ii) análise do plano de expressão, com exemplificação das relações de dependência entre os formantes e o estabelecimento de categorias; e iii) explicitação do caráter isomórfico nos dois planos da linguagem. Aos três passos propostos pela autora, adotamos um último nesta avaliação: iv) verificação dos resultados isomórficos com a apreensão do conteúdo manifestada pelos interagentes nas redes sociais online no ambiente primeiro do enunciado.

Ainda reconhecendo que, conforme reforça Oliveira (2009), a teoria semiótica trate o sujeito do enunciado como instalado no próprio objeto sincrético, cabe aproveitar a natureza pós-massiva das redes sociais online, espaço onde se situa o corpus desta pesquisa, para, em uma avaliação para além do texto sincrético, verificar como se deu a apreensão do campo de conteúdo pelos enunciatários. Ainda que tal avaliação pareça mais comparativa do que propriamente semiótica, a possibilidade de que o enunciatário se manifeste no mesmo espaço em que o conteúdo é divulgado é elemento de grande relevância dentro do contexto comunicativo que fundamenta esta pesquisa. Mesmo entendendo que uma análise semiótica mais profunda dos comentários postados pelos interagentes é tarefa para pesquisas posteriores, seria um descuido imperdoável ignorar um estudo inicial - ainda que, como já dito, comparativo - que refute ou referende em tal conteúdo a avaliação do videocase à luz da semiótica sincrética.

\section{Videocase "Badass": machismo e homofobia em diferentes linguagens}

Seguindo a sugestão de Médola (2009), para facilitar o entendimento e apreensão do leitor desta pesquisa sobre o corpus, optou-se por, inicialmente, elaborar uma descrição detalhada do videocase estudado, apresentada na Tabela 1. Na sequência, 
para ilustrar a dinâmica do vídeo, são expostas as imagens 2, 3, 4, 5 e 6, referentes, respectivamente, às telas congeladas dos takes $1,5,10 / 11,21$, e 30/31.

Tabela 1 - Descrição por takes do videocase estudado.

\begin{tabular}{|c|c|}
\hline Take & Descrição \\
\hline 1 & $\begin{array}{l}\text { Câmera em movimento. Homem caminha pela sessão de produtos de } \\
\text { beleza do supermercado (Imagem 2). Presença da locução em off com o } \\
\text { texto: "Os homens se orgulham de muita coisa". }\end{array}$ \\
\hline 2 & Câmera próxima. Mão masculina com machado cortando lenha. \\
\hline 3 & Câmera próxima. Mão masculina com britadeira em ação. \\
\hline 4 & Câmera próxima. Mão masculina trocando lâmpada. \\
\hline 5 & Câmera próxima. Mão masculina abrindo uma lata (Imagem 3). \\
\hline 6 & Câmera próxima. Mão masculina matando inseto. \\
\hline 7 & Câmera próxima. Braços masculinos disputando uma "queda-de-braço" \\
\hline 8 e 9 & $\begin{array}{l}\text { Câmera panorâmica e depois próxima. Homem constrangido em pegar um } \\
\text { shampoo na prateleira. Presença da locução em off com o texto: "Mas } \\
\text { comprar shampoos nunca foi uma delas". }\end{array}$ \\
\hline 10 e 11 & $\begin{array}{l}\text { Câmera panorâmica mostrando um homem e uma criança e depois, fechada } \\
\text { no homem. Criança ri debochando (Imagem 4). }\end{array}$ \\
\hline $\begin{array}{c}11 \text { ao } \\
15\end{array}$ & $\begin{array}{l}\text { Câmera panorâmica e fechada. Luz se apaga. Homem se aproxima da } \\
\text { geladeira com shampoos. Locução em off apresenta o shampoo anunciado: } \\
\text { "o primeiro shampoo masculino que vem em uma garrafa de cerveja". }\end{array}$ \\
\hline 16 & $\begin{array}{l}\text { Câmera panorâmica e depois próxima. Homem passeia com os amigos pela } \\
\text { sessão de beleza. Todos esbanjam autoconfiança e têm os shampoos nas } \\
\text { mãos. Locução em off com o texto: "Porque nenhum homem deveria se } \\
\text { sentir menos homem na hora de comprar o seu shampoo". }\end{array}$ \\
\hline 17 & Tela preta com o texto verbal: "Resultados". \\
\hline 18 & Tela preta com o texto verbal: "Antes". \\
\hline 19 & $\begin{array}{l}\text { Câmera próxima. Mulher entra no elevador e ri, ao perceber que o homem } \\
\text { tem um shampoo semelhante na sacola de compras. }\end{array}$ \\
\hline 20 & Tela preta com o texto verbal: "Depois". \\
\hline 21 & $\begin{array}{l}\text { Câmera próxima. Mulher entra no elevador e flerta com o homem ao } \\
\text { perceber que ele um shampoo "Badass" na sacola de compras (Imagem 5). }\end{array}$ \\
\hline
\end{tabular}




\begin{tabular}{|c|c|}
\hline 22 & Tela preta com o texto verbal: "Antes". \\
\hline 23 & $\begin{array}{l}\text { Câmera próxima. Homem toma banho dançando com um shampoo rosa e } \\
\text { ouvindo música pop. }\end{array}$ \\
\hline 24 & Tela preta com o texto verbal: "Depois". \\
\hline 25 & $\begin{array}{l}\text { Câmera próxima. Homem toma banho, cantando rock-and-roll com o } \\
\text { shampoo "Badass". }\end{array}$ \\
\hline 26 & Tela preta com o texto verbal: "Antes". \\
\hline 27 e 28 & $\begin{array}{l}\text { Câmera próxima e depois panorâmica. Homem pega shampoo rosa no } \\
\text { vestiário e demais homens se afastam. }\end{array}$ \\
\hline 29 & Tela preta com o texto verbal: "Depois". \\
\hline 30 e 31 & $\begin{array}{l}\text { Câmera próxima e depois panorâmica. Homem pega shampoo "Badass" e } \\
\text { mostra aos demais homens no vestiário, que celebram (Imagem 6). }\end{array}$ \\
\hline 32 e 33 & $\begin{array}{l}\text { Exibição das marcas do shampoo e da empresa. Locução: “(...) seus } \\
\text { cabelos não perdem o brilho e você não perde a masculinidade”. }\end{array}$ \\
\hline
\end{tabular}

Fonte: elaboração própria.

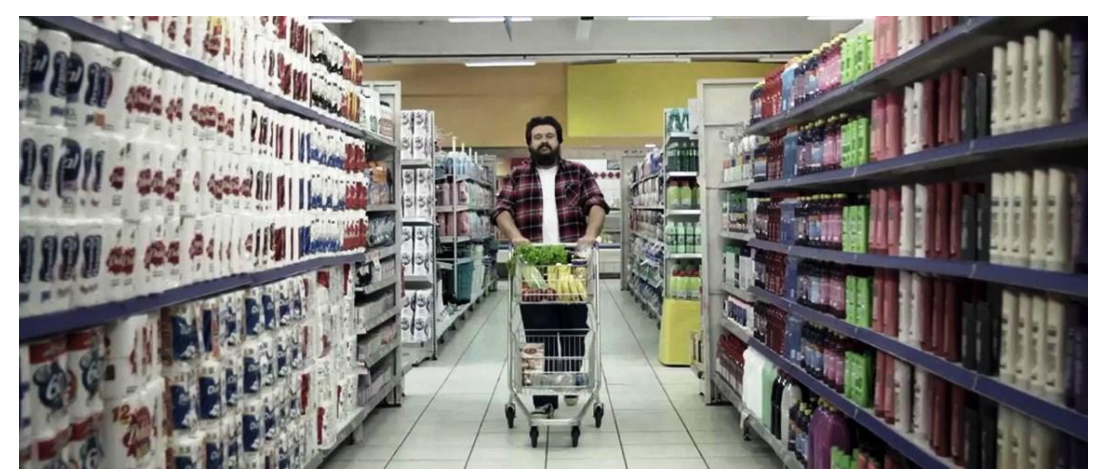

IMAGEM 2

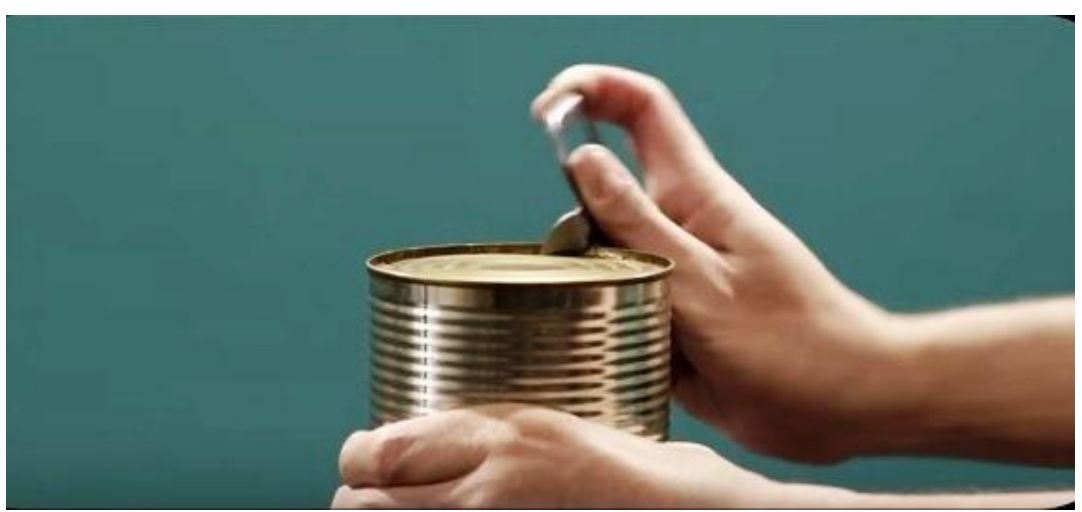

IMAGEM 3 


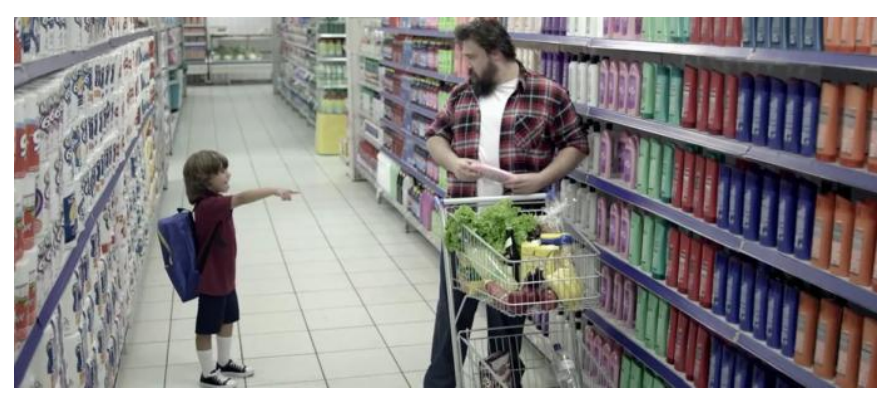

IMAGEM 4

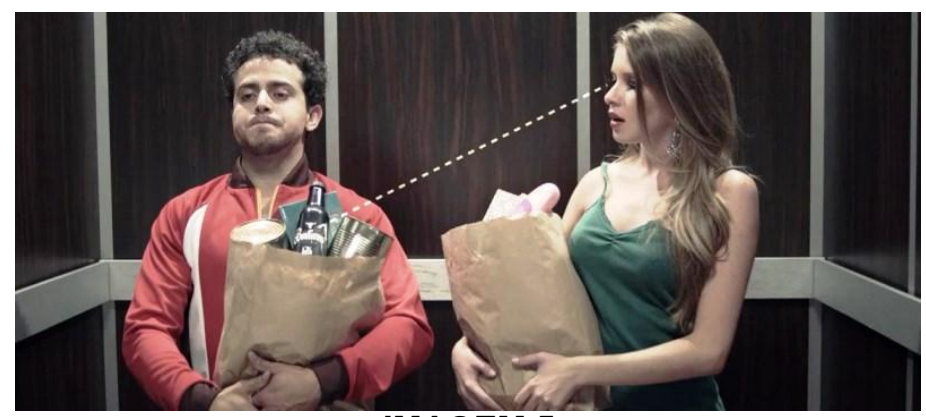

IMAGEM 5

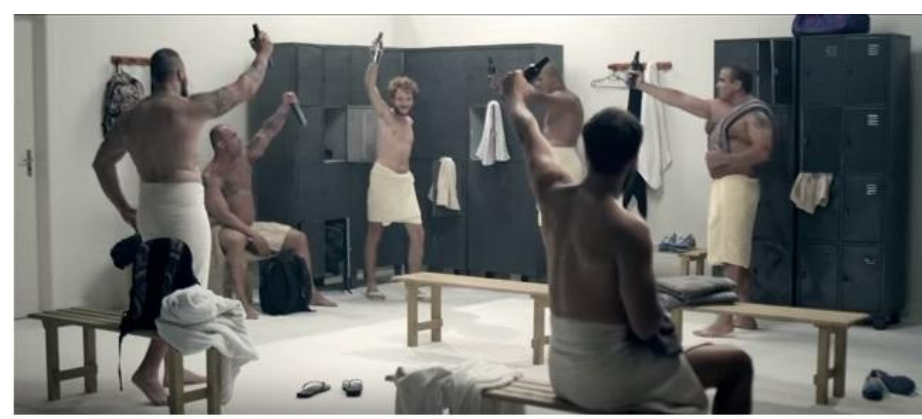

IMAGEM 6

Uma vez decupado o vídeo em estudo, retomamos o caminho proposto por Médola (2009), realizando um inventário das linguagens presentes na propaganda. No campo visual, encontramos o imagético, a linguagem videográfica, o gestual e o verbal escritos, além da inserção de infográficos/animações em situações específicas. No campo sonoro, por sua vez, encontramos a locução em off do vídeo (verbal falado), a vinheta, trilhas e diversos efeitos sonoros: barulho de portas de elevador se abrindo, britadeira em funcionamento, som divino que ilumina o dispositivo com os shampoos "Badass", a risada da criança. Todas essas linguagens são incorporadas pelo audiovisual, responsável por dar dinâmica ao objeto sincrético.

Considerando que o imagético, através da linguagem videográfica, incorpora os infográficos, as animações, o gestual e o verbal escrito, é notório que ele domina toda a propaganda, apresentando-se como uma linguagem constante durante os 94 segundos da narrativa. Já o verbal escrito (se avaliado individualmente) e o verbal falado (presente 
na locução em off) ocupam apenas 9 takes cada, muitos deles servindo apenas como elementos transitórios entre as tomadas - como as palavras "Antes" e "Depois". Quando consideramos a trilha sonora e as vinhetas, essas também aparecem como linguagem constante, mas incapaz de determinar sentido sem a atuação de outra linguagem. Percebe-se, portanto, que o imagético se põe como principal linguagem da obra. Assim, para analisar a hierarquia de dependências entre as linguagens, que, conforme ressalta Médola (2009), podem estar organizadas de forma bilateral ou multilateral, traçou-se a tabela 2.

Tabela 2 - Linguagens presentes no videocase.

\begin{tabular}{|c|c|}
\hline Linguagem & Frequência \\
\hline Imagética (gestual, animação, videográfica) & Constante (C) \\
\hline Verbal (falada e escrita) & Variável (V) \\
\hline Sonora (apenas vinhetas e efeitos) & Constante $(\mathrm{C})$ \\
\hline
\end{tabular}

Considerando a categorização apresentada na Tabela 2, pode-se dizer que são dois os cruzamentos de linguagens possíveis, no vídeo: imagético (C) com sonoro (C); imagético e sonoro [ou audiovisual (C)] com verbal (V). Tomando as categorias de sincretismo propostas por Oliveira (2009), é possível perceber que o sincretismo do imagético com o sonoro ocorre por contração, uma vez que, individualmente, as vinhetas ou efeitos sonoros não conseguiriam passar a mensagem, configurando apenas um emaranhando de sons sem sentido.

O imagético, por sua vez, ainda que sem a linguagem sonora, consegue demonstrar - na maioria dos takes apenas pelo gestual - os valores presentes no plano de conteúdo (que será detalhado a seguir). Portanto, nessa relação, ocorre uma contração onde o imagético impõe seu sentido sobre o sonoro. Já ao pensar o segundo momento possível, com a inserção da variável verbal (falada ou escrita) ao conjunto audiovisual, nota-se um sincretismo por união, uma vez que as linguagens constantes operam por reciprocidade com a variável, cada qual contribuindo para reforçar o valor presente na outra.

Tomando a categorização realizada para iniciar a avaliação do plano de conteúdo, constata-se, em um nível mais profundo, o valor /masculinidade/ como tema principal de toda a propaganda. Outrossim, percebe-se que /masculinidade/ aparece sempre em disjunção com valores como /shampoo/ e /rosal; e em conjunção com 
valores como /forçal. Cabe, porém, problematizar que, por oposição, estes valores colocam /mulher/ em disjunção com /forçal e /shampoo e rosal em conjunção com /debochel, /homossexualidadel, /isolamento/ e /solidão/.

Partindo já para a observação do plano de expressão, quando consideradas as diferentes linguagens, percebe-se que os valores que constroem a temática principal do plano de conteúdo são constantemente reforçados em todas as categorias. Ao observar o valor /masculinidade/ em disjunção com o valor/rosa/, por exemplo, nota-se que, já no décimo take, aos 15 segundos de vídeo, o sincretismo trabalha em união para reforçar a ideia: no imagético gestual, o homem fica constrangido ao pegar o shampoo rosa e derruba os demais produtos da prateleira; em paralelo, ainda no imagético, uma criança começa a debochar do homem, apontando para ele (Imagem 4); já no campo sonoro, a locução em off afirma que o homem não tem orgulho de comprar shampoo, complementando o embaraço demonstrado pelo gestual; a risada da criança, por sua vez, persiste, mesmo quando a luz se apaga e a cena termina, reforçando a sensação continuada de vergonha.

O mesmo paralelo de valores surge a partir do take 17, quando o verbal escrito complementa o audiovisual demarcando os sujeitos de estado e os sujeitos do fazer, reforçando quadro a quadro com a união de diferentes linguagens a oposição. A relação fica mais explícita entre os takes 22 e 25, quando, primeiro, imagem e som se unem para reforçar a conjunção de /homossexualidadel com /rosal, ao mostrar um homem tomando banho e cantando música pop (sujeito de estado) para, em seguida, reforçar a disjunção entre /Badass/ e /homossexualidadel, ao mostrar um homem tomando banho escutando rock-and-roll.

Tomando a temática proposta na introdução desta pesquisa, a saber, a discussão de gênero que nos leva aos debates sobre machismo e homofobia, dentro da publicidade pós-massiva, é notório que as pautas surgem como valores na propaganda em diferentes condições. Ao trazer como temática principal o valor /masculinidade/, por disjunção, a pauta /homossexualidade/ acaba ocupando grande espaço no percurso narrativo. Além do trecho explicitado no parágrafo anterior (que expõe do take 22 ao 25), tal oposição é reforçada de forma mais notória entre os takes 26 e 31, onde /rosa/ entra em conjunção com /homossexualidadel e /isolamento/; e /Badass/ com /masculinidadel e /companheirismo/. Já o valor /machismo/ fica mais evidente nos takes iniciais, quando /forçal e /habilidades manuais/ são colocados em disjunção com /mulher/, em uma narrativa reforçada pelo imagético, que traz homens trabalhando, e pela locução em off 
que sugere que tais feitos são orgulho dos homens. Além disso, a temática retorna na cena do elevador (takes 18 ao 21), onde novamente a linguagem verbal marca a transição do sujeito de estado para o sujeito do fazer e o imagético reforça a disjunção entre /masculinidade/ e /rosa/. Nessas últimas tomadas descritas, especificamente, ganha grande importância a animação que, através de um tracejado mostra, inicialmente, o deboche da mulher em relação ao shampoo rosa na sacola de compras do homem (/rosal em disjunção com /sedução/ e /masculinidade/); para depois mostrar a atração da mulher pelo homem com "Badass", colocando em conjunção valores machistas como a dependência da mulher pelo homem ou a preferência por homens não afeminados (/mulher/ conjunção /busca por homens viris/).

\section{Considerações finais: isotopia e aproximação com comentários no Facebook}

Ainda considerando o modelo proposto por Médola (2009), uma vez estabelecidas as categorias de linguagens, no texto sincrético e esgotadas as observações iniciais dos planos de conteúdo e expressão, faz-se necessário observar a isotopia no objeto, isto é: listar quais temáticas se repetiram ao longo da peça audiovisual. No caso observado, por se tratar da temática principal do videocase, a disjunção entre Imasculinidadel e Irosal foi constante, nos 94 segundos de duração do trabalho audiovisual, sendo reforçada pelo sincronismo de união estabelecido entre as diferentes linguagens. Porém, cabe reforçar que, desses dois temas, outras temáticas foram propostas e reforçadas, durante todo o videocase, surgindo com grande ênfase - como se esperava com a escolha da obra - as temáticas /homossexualidade/ e /mulher/.

Ao reiterar de maneira repetitiva - e a partir do sincretismo pela união de diversas linguagens - a necessidade de afirmação do homem em relação aos homossexuais e em relação às mulheres, observa-se, a partir da análise semiótica apresentada, que o vídeo acaba deslocando o olhar do enunciatário da disjunção entre os valores /masculinidade/ e /rosa/ para a disjunção entre os valores /homem/ e /mulher/; e /homem/ e /homossexuais/. Tal deslocamento na narrativa causa a sensação angustiante, aos olhos do pesquisador de uma produção publicitária que reforça valores conservadores e retrógrados presentes na sociedade, sobretudo pelo abuso - ainda pensando no sincrético - de gestuais e situações estereotipadas - conforme previsto no referencial que orientou a análise (DINIZ, 2006).

Cumprindo a última etapa da investigação, avaliaram-se, a efeito comparativo com o que podemos estabelecer como senso comum da era pós-massiva, os cem 
comentários listados como "mais populares" sobre o videocase - em um conjunto de aproximadamente 4 mil comentários - de acordo com os critérios apresentados pelo coeficiente semântico do próprio Facebook ${ }^{6}$. Nesse universo, embora as temáticas secundárias /machismo/ e /homofobia/ não tenham aparecido no plano de expressão, elas aparecem constantemente no plano de conteúdo. Entre os 91 comentários que criticaram o videocase, em 54 o valor /masculinidadel foi explicitado no plano de expressão, mostrando que a temática principal foi compreendida pelos enunciatários. Porém, no lugar da pretendida disjunção com /rosa/, imperou a conjunção com os valores /fragilidadel e /machismo/. Assim, no universo analisado, em apenas 9 comentários o valor /masculinidade/ atuou em conjunção com /Badass/, seguindo o que podemos entender como objetivo original do videocase.

Considerando a proximidade entre o resultado da pesquisa semiótica e o efeito sobre os enunciatários, pode-se afirmar o êxito da análise à luz da semiótica sincrética para interpretar produtos da era pós-massiva, o que nos suscita propor novos testes e pesquisas, sobretudo com objetos da publicidade, sincréticos por natureza. Por fim, tomando a temática mais ampla, é importante destacar o xeque imposto aos mass media: o choque entre a opinião pública presente na era pós-massiva e o discurso midiático, conforme demonstrado no videocase estudado, é inevitável. Assim, uma constatação interessante nesta pesquisa é a afinidade entre os resultados da investigação semiótica e a apreensão discursiva externada pelos interagentes, nos comentários online. Entendendo que o receptor nunca foi passivo, como última contribuição, propõem-se novas investigações à luz da semiótica sincrética, sobre a influência decisiva dos enunciatários, para a formação da opinião pública, na era pós-massiva.

\section{Referências bibliográficas}

ALTHUSSER, L. Aparelhos ideológicos de estado: nota sobre os aparelhos ideológicos de estado. 3 ed. Rio de Janeiro: Graal, 1985.

CARRASCOZA, J. A evolução do texto publicitário. São Paulo: Futura, 1999.

CARVALHO, C. Jornalismo, homofobia e relações de gênero. Curitiba: Appris, 2012.

CRESTANI, L. Sincretismo de linguagens e efeitos de sentido no jornalismo online. In: Revista do Programa de Pós-Graduação em Letras da Universidade de Passo Fundo - v. 10 - n. 2 - p. 456-474 - jul./dez. 2014

\footnotetext{
${ }^{6}$ Embora não torne público seu coeficiente semântico, seguir o recorte apresentado pelo Facebook como delimitador para a pesquisa é um facilitador importante para avaliar informações nesta rede social.
} 
DINIZ, M. Estereótipo na mídia doxa ou ruptura. In: COELHO, J., GUIMARÃES, L., VICENTE, M. (orgs.). O futuro: continuidade - ruptura: desafios para a Comunicação e para a Sociedade. São Paulo: Annablume, 2006. p. 137-146.

FIORIN, J.L. Para uma definição das linguagens sincréticas. In: OLIVEIRA, A.C; TEIXEIRA, L (orgs). Linguagens na comunicação: desenvolvimentos de semiótica sincrética. São Paulo: Estação das Letras e Cores, 2009. p. 15 - 40.

FREIRE, P. Pedagogia do Oprimido. $5^{\mathrm{a}}$ ed. Rio de Janeiro: Paz e Terra, 1978.

LEMOS, A.; LÉVY, P. O futuro da internet: em direção a uma ciberdemocracia planetária. São Paulo: Paulus, 2010.

MÉDOLA, A.S. Lógicas de articulação de linguagem no audiovisual. In: OLIVEIRA, A.C; TEIXEIRA, L (orgs). Linguagens na comunicação: desenvolvimentos de semiótica sincrética. São Paulo: Estação das Letras e Cores, 2009. p. 401 - 420.

MEDITSCH, E.; FARACO, M. O Pensamento de Paulo Freire sobre Jornalismo e Mídia. In: Intercom - Revista Brasileira de Ciências da Comunicação, Rio de Janeiro, v.26, n.1, 2003. Disponível em: <http://www.portcom.intercom.org.br/revistas $>$. Acesso em: 15 de fevereiro de 2016.

MÉNDEZ, N. Feminismo, imprensa e poder no Brasil contemporâneo. In: MÉTIS: história \& cultura - v. 6, n. 12, p. 269-288, jul./dez. 2007.

OLIVEIRA, A.C. A plástica sensível da expressão sincrética e enunciação global. In: OLIVEIRA, A.C; TEIXEIRA, L (orgs). Linguagens na comunicação: desenvolvimentos de semiótica sincrética. São Paulo: Estação das Letras e Cores, 2009. p. $79-144$.

PEREIRA, D.; MATTE, A. Discursos sobre a Web 2.0 e a educação: uma análise semiótica. In: Trabalhos de Linguística Aplicada, Campinas, 49(1): 293-304, jan./jul. 2010.

PRIMO, A. O aspecto relacional das interações na Web 2.0. In: E- Compós (Brasília), v. 9, p. 1-21, 2007.

Quão interativo é o hipertexto? Da interface potencial à escrita coletiva. In Fronteiras: Estudos Midiáticos, São Leopoldo, v. 5, n. 2, p. 125-142, 2003.

SOIHET, R. Sutileza, ironia e zombaria: instrumentos no descrédito das lutas das mulheres pela emancipação. In: MURARO, R.M. Mulher, gênero e sociedade. Rio de Janeiro: Relume Dumará, 2001.

TEIXEIRA, L. Para uma metodologia de análise de têxtis verbovisuais. In: OLIVEIRA, A.C; TEIXEIRA, L (orgs). Linguagens na comunicação: desenvolvimentos de semiótica sincrética. São Paulo: Estação das Letras e Cores, 2009. p. 41 - 78. 